\title{
Preface
}

\section{Education, Outreach and Defining Users (Geo- and Space-physical Sciences)}

\author{
N. B. Crosby ${ }^{1}$, R. A. Pertzborn ${ }^{2}$, and V. Rosmorduc ${ }^{3}$ \\ ${ }^{1}$ Belgian Institute for Space Aeronomy, Ringlaan-3-Avenue Circulaire, 1180 Brussels, Belgium \\ ${ }^{2}$ Office of Space Science Education, University of Wisconsin-Madison, Space Science and Engineering Center, $1225 \mathrm{~W}$. \\ Dayton Street, Madison, WI 53706, USA \\ ${ }^{3}$ Collecte Localisation Satellites, Direction Océanographie Spatiale (CLS/DOS), 8-10 rue Hermes, Parc Technologique du \\ Canal, 31526 Ramonville St-Agne, France
}

This special issue is devoted to papers concerning the subject matter "education, outreach and defining users" in the geo- and space-physical communities. Users represent every sector of society from schools, to the general public and companies. It is important to understand the unique needs and interest of each user community. Science education needs for a classroom of children are very distinct from adults working at a company.

The papers were presented during the session "Geo- and Space-physical Sciences (Education, Outreach and Defining Users)" held during the European Geosciences Union (EGU) first General Assembly in Nice, France, 25-30 April 2004. Due to the various EGU communities represented during this session (e.g., space physics and astronomy, earthquake science, oceanography) and the international background of the speakers (Denmark, Finland, France, Italy, Russia, Sweden, Turkey, USA) the session was indeed a success. The goal of this special issue is to bring together people working on the broad physical science covered by the different EGU communities for the current and future mutually beneficial exchange of ideas and experiences.

The Editorial team listed below would like to thank all of the authors of the submitted papers for their enthusiasm, as well as manuscript reviewers for contributing their valuable time and input. A special thanks goes to "Advances in Geosciences" for accepting to publish this first special issue focusing on Education and Outreach.

\section{Norma B. Crosby}

Rosalyn A. Pertzborn

Vinca Rosmorduc

Editors 